\title{
A Meta-Analysis of the Relationship Between Emotional Intelligence and Effective Leadership
}

\author{
Lane B. Mills \\ East Carolina University
}

\begin{abstract}
The purpose of this study was to conduct a meta-analysis to ascertain if there was empirical evidence to support the inclusion of emotional intelligence as a component of effective leadership. It is proposed in this paper that emotional intelligence is a component of transformative leadership that should be evaluated and developed. In order to conduct the study, precise, composite definitions of emotional intelligence and effective leadership were drawn from the respective literature. One hundred and forty-one studies were reviewed for possible analysis with 48 studies meeting the criteria for inclusion. The study concludes that there is a moderately strong relationship between emotional intelligence and effective leadership. This study has implications for candidates of Educational Leadership Preparation Programs and the incorporation of emotional intelligence in the Educational Leadership Preparation Programs curriculum.
\end{abstract}

One skill set frequently cited in the literature on leadership as necessary in a variety of situations is the intrapersonal and interpersonal skills associated with emotional intelligence (Downey, Papageorgiou, \& Stough, 2006; Dulewicz \& Higgs, 2003; Rosete \& Ciarrochi, 2005). While there are numerous studies that provide empirical evidence that emotional intelligence has a positive effect on leadership effectiveness (Coetzee \& Schaap, 2004; Kerr, Garvin, Heaton, \& Boyle, 2006; Goleman, 1995,1998; Leban \& Zulauf, 2004; Srivastava \& Bharamanaikar, 2004; Wong \& Law, 2002), studies also reflect that emotional intelligence has no statistical significance in leadership effectiveness (Barbuto \& Burbach, 2006; Barchard, 2003; Brown, 2005; Brown, Bryant, \& Reilly, 2006; Schulte, 2002; Weinberger, 2003).

The purpose of this study was to conduct a meta-analysis to ascertain if a consistent, research-based link can be established between the concept of emotional intelligence and effective leadership. If this link can be established, it could have a significant impact on the selection and preparation of educational leaders. This linkage would also have implications for the exercise of leadership in educational arenas.

A meta-analysis can be defined as "the statistical analysis of a large collection of analysis results from individual results for the purpose of integrating the findings" (Glass, McGaw, \& Smith, 1981, p. 3). Given the ongoing question in the literature of whether emotional intelligence affects leadership effectiveness, the incorporation of a meta-analysis might provide a more robust method to examine this relationship. A metaanalysis conducted by Van Rooy and Viswesvaran (2004) to predict workplace performance based on the level of emotional intelligence provided a starting point for 
the current study, but this meta-analysis did not focus on leadership effectiveness as a specific concern for those associated with Educational Leadership Preparation Programs (ELPP).

\section{Transformational Leadership and Emotional Intelligence}

The concept of transformational leadership may provide a model for interpreting the relevance of emotions to leadership (Ashforth \& Humphrey, 1995). According to Bass and Avolio (1993), there are four dimensions to transformational leadership: (a) idealized influence, (b) inspirational motivation, (c) intellectual stimulation, and (d) individualized consideration. Transformational leadership skills, based on these dimensions, might be considered to be intertwined with the concepts of emotional intelligence in the literature. Skills reflective of an emotional intelligence framework such as identifying and relating emotionally to others, acknowledging the needs, wishes, and feelings of subordinate individuals in an organization, or arousing emotions to foster change and commitment have been reflected in transformational leadership studies (Andersen, 2000; Ashforth \& Humphrey, 1995; Hoffman \& Frost, 2006). Table 1 shows a strong resemblance between transformational leadership and emotional intelligence no matter which model is examined (Ashkanasy, Hartel, \& Daus, 2002).

Table 1

Comparison of Transformational Leadership Components with Emotional Intelligence Models

\begin{tabular}{|c|c|c|c|c|}
\hline \multicolumn{5}{|c|}{ Essential Elements of Emotional Intelligence Models } \\
\hline $\begin{array}{c}\text { Transformational } \\
\text { Components } \\
\begin{array}{c}\text { Idealized } \\
\text { Influence }\end{array}\end{array}$ & $\begin{array}{c}\text { Bar-On } \\
\mathbf{( 2 0 0 6 )}\end{array}$ & $\begin{array}{c}\text { Dulewicz and Higgs } \\
\mathbf{( 2 0 0 0 )}\end{array}$ & $\begin{array}{c}\text { Mayer and } \\
\text { Salovey (1997) }\end{array}$ & $\begin{array}{c}\text { Goleman et } \\
\text { al. (2002) }\end{array}$ \\
\hline $\begin{array}{c}\text { Inspirational } \\
\text { Motivation } \\
\text { Management }\end{array}$ & $\begin{array}{c}\text { General } \\
\text { Mood }\end{array}$ & Motivation & $\begin{array}{c}\text { Managing } \\
\text { Emotions }\end{array}$ & $\begin{array}{c}\text { Relationship } \\
\text { Management }\end{array}$ \\
\hline $\begin{array}{c}\text { Intellectual } \\
\text { Stimulation }\end{array}$ & Adaptability & Intuitiveness & $\begin{array}{c}\text { Facilitating } \\
\text { Thought }\end{array}$ & \\
\hline $\begin{array}{c}\text { Individualized } \\
\text { Consideration }\end{array}$ & Interpersonal & Interpersonal Sensitivity & $\begin{array}{c}\text { Perceiving } \\
\text { Emotions }\end{array}$ & $\begin{array}{c}\text { Social } \\
\text { Awareness }\end{array}$ \\
\hline & Stress & Emotional resilience & Understanding \\
Emotions & Self \\
& Managementens \\
\hline & & Self Awareness & & \\
\hline
\end{tabular}

Empirical links with emotional intelligence and transformational leadership behaviors are reported in the literature. Barling, Slater, and Kelloway's study (2000) revealed emotional intelligence's association with three aspects of transformational 
leadership (idealized influence, inspirational motivation, and individualized consideration) using Bar-On's 1997 mixed model. In addition, Leban and Zulauf's 2004 study assessing emotional intelligence using an ability-based model (Mayer-SaloveyCaruso Emotional Intelligence Ability Test (MSCEIT)) and measure of leadership style (the Multifactor Leadership Questionnaire (MLQ)), found the overall emotional intelligence score and the ability to understand the emotions branch of the MSCEIT shared a significant correlation with the inspirational motivation subscale of the MLQ. The strategic use of emotional intelligence also shared a significant correlation with idealized influence and individual consideration. Mandell and Pherwani (2003) provide empirical evidence to support that emotional intelligence and transformational leadership are based on relationships and interrelated concepts. Specifically, the study reported that emotional intelligence scores could predict transformational leadership style. Sivanathan and Fekken (2002) reported followers' evaluations of leaders' transformational behaviors were positively related to leaders' self-reports of emotional intelligence and ratings on leadership effectiveness. The above examples help to illustrate that leadership research considers the linkage between emotional skills of leaders and effectiveness and suggests that emotional intelligence shares a link with many of the elements that comprise transformational leadership.

\section{Defining Effective Leadership and Emotional Intelligence}

The question of definitions of variables is a particularly critical component of any meta-analysis. The problem of defining leadership is well established in the literature (Bass, 1990; Collins, 2001; Nahavandi, 2003; Northouse, 2006; Stogdill, 1974). Stogdill said that "there are almost as many different definitions of leadership as there are people who have tried to define it" (p. 7). Collins contends that vague, expansive definitions of leadership create problems when analyzing organizational issues.

When we define leadership by ascribing unlimited and undifferentiated functions and activities in an organization to leadership, according to Collins (2001, p. 22)., we have really not defined leadership at all. We have simply thrown up our hands in frustration and "we prevent ourselves from gaining deeper, more scientific understanding about what makes companies tick".

Although acknowledging the difficulty of providing a precise definition of leadership, Nahavandi (2003) and Northouse (2006), after conducting comprehensive reviews of the leadership literature, have found elements common to the phenomena of leadership no matter where or how leadership is exercised. Both Nahavandi and Northouse list three common elements: (a) Leadership involves interaction with a group, (b) Leadership involves the exercise of influence, and (c) Leadership involves the attainment of a goal.

Once we have established a reasonably precise definition of leadership then effective leadership must be defined. Northouse (2006) stated that leadership effectiveness is measured by the attainment of goals or objectives within a leadership context. Hartman (1999) contends that leadership effectiveness is defined both 
objectively and subjectively. Subjective measures are usually based on ratings obtained from the leader's superiors, peers, or subordinates. Examples of objective measures of performance or goal attainment can include profits, profit margin, test scores, graduation rates, sales increases, market shares, or profitability (Hartman, 1999). The two instruments used to measure leadership effectiveness most frequently cited in the studies included in the meta-analysis were the Multifactor Leadership Questionnaire (MLQ) and the Leadership Practices Inventory (LPI). The MLQ, developed by Bass and Avolio (2000), is a 45-item questionnaire that attempts to determine the multiple factors constituting a person's leadership style. The Leadership Practices Inventory (LPI), developed by Kouzes and Posner (1995), has been used to assess over 350,000 individuals' leadership skills. It is based on qualitative and quantitative research of everyday actions and behaviors of exemplary leaders in a variety of settings.

Researchers classify their conception of emotional intelligence as either ability models or mixed models. Ability models of emotional intelligence focus on the interplay of emotion and intelligence as traditionally defined while mixed models describe a conception of intelligence that includes mental abilities and other traits and talents including personality (Mayer, Salovey, \& Caruso, 2000). Drawing from diverse elements of the literature, emotional intelligence was defined for the purpose of this study as the advanced ability to use self awareness and insight into self and others' emotion to aid in cognitive processes to produce desired outcomes (Bar-On, 1997; Dulewicz \& Higgs 2000; Goleman, 1998; Mayer, Salovey, \& Caruso, 2000; McEnrue \& Groves, 2006). One of the most frequently used instruments to measure emotional intelligence cited in this meta-analysis was the Mayer-Salovey-Caruso Emotional Intelligence Test (MSCEIT) (Multi Health Systems, Inc, 2002). The MSCEIT is an ability-based scale that measures the capacity to reason using feelings and the capacity of feelings to enhance thought.

\section{Pertinent Literature}

As mentioned earlier, the meta-analysis performed in 2004 by Van Rooy and Viswesvaran was of assistance in informing this meta-analysis of the relationship between emotional intelligence and effective leadership. It is important to note that the Van Rooy and Viswesvaran study focused on work place performance and emotional intelligence. Also critical to the validity of this analysis were studies that questioned whether emotional intelligence had a significant effect on leadership effectiveness (Brown, Bryant, \& Reilly, 2006; Buford, 2001; Collins, 2001; Schulte, 2002; Weinberger, 2003). For example, one study (Antonakis, 2004) included in the meta-analysis cites the claims that emotional intelligence apparently is twice as important as IQ or technical skills for leadership effectiveness as the main argument against emotional intelligence (see also Goleman, 1998). As stated by Mayer and Caruso (2002), emotional intelligence is an important capability, but one that co-exists with other strengths and weaknesses. The inclusion of Antonakis' study and other work that questioned the linkage of emotional intelligence to leadership effectiveness or stated specifically that emotional intelligence did not contribute to leadership effectiveness provide more credibility for the ultimate conclusions of the study. 


\section{Methods and Results}

The comprehensive attempt to identify relevant studies on emotional intelligence's impact on leadership effectiveness conducted between 1990 to the present yielded 141 studies. Forty-eight studies met the criteria for inclusion in the meta-analysis sample. Those 48 studies yielded 99 correlations for analysis. Over half of the studies included in this study were in the form of unpublished dissertations (48\%) and theses (8\%) with forty-one percent of participants reported serving in the field of business or industry.

Determining the degree of homogeneity of the studies included in a metaanalysis helps to determine the statistical model to be used. A Q statistic was computed to explore whether the variability across effect sizes was greater than expected from sampling error alone. Based on a significant result for the $Q$ statistic for these data, the hypothesis of homogeneity was rejected and a random-effects model was implemented. This significant $Q$ statistic result was not unexpected given the essential random differences between studies that were associated with the framework of emotional intelligence chosen and other study variables (e.g., the framework of leadership effectiveness, occupational setting). Incorporating a random effects model allows for the estimation of the mean of effects which prevents the underestimation of the weight of a small study or the overestimation of the weight of a large study (Borenstein et al., 2007).

Using Biostat's Comprehensive Meta-Analysis Software Version 2.0 (Borenstein, Hedges, Higgins, \& Rothstein, 2005), the 99 effect sizes from the correlational studies with a total of 7,343 subjects were converted into Fisher $Z$ scores and an overall effect size $z$ was computed and converted to the initial metric of correlation coefficient. Based on the rule of thumb for judging the magnitude of the product moment correlation effect size suggested by Lipsey and Wilson (2001), correlation effect size values are considered small if less than or equal to .10 , medium if equal to .25 , and large if greater than or equal to .40 . This meta-analysis yielded a combined effect of $r=.380$ which can be interpreted as a moderately strong relationship between emotional intelligence and leadership effectiveness. Although claims of the paramount or essential value of emotional intelligence as a component of leadership may be overstated, it would appear that emotional intelligence is at least an important element in the exercise of effective leadership. This finding can have significance for the evaluation of educational leaders. It would appear that emotional intelligence should be included in the formative evaluation of educational leaders. Table 2 provides a summary of the studies included in the meta-analysis. 
Table 2

\begin{tabular}{|c|c|c|c|c|c|}
\hline \multicolumn{6}{|c|}{ Summary of Studies Included in Meta-Analysis } \\
\hline \multirow[b]{2}{*}{ Study } & \multirow[b]{2}{*}{ Source } & \multirow[b]{2}{*}{$\mathrm{n}$} & \multirow[b]{2}{*}{$r$} & \multicolumn{2}{|c|}{$95 \% \mathrm{Cl}$} \\
\hline & & & & $\begin{array}{l}\text { Lower } \\
\text { limit }\end{array}$ & $\begin{array}{l}\text { Upper } \\
\text { limit }\end{array}$ \\
\hline Batastini, S.D. (2001) & Dissertation & 15 & 0.619 & 0.156 & 0.859 \\
\hline Baumann, D. M. (2006) & Dissertation & 62 & 0.648 & 0.475 & 0.773 \\
\hline BeShears, R. S. (2004) & Dissertation & 159 & 0.453 & 0.320 & 0.569 \\
\hline Bradberry, T. R. (2003) & Dissertation & 212 & 0.747 & 0.681 & 0.801 \\
\hline $\begin{array}{c}\text { Brown, F. W., Bryant, S. E., } \\
\text { \& Reilly, M. D. (2006) }\end{array}$ & Journal Article & 95 & 0.040 & -0.163 & 0.240 \\
\hline Buford, B. A. (2001) & Dissertation & 108 & 0.336 & 0.130 & 0.514 \\
\hline Burbach, M. E. (2004) & Dissertation & 146 & 0.150 & -0.013 & 0.305 \\
\hline Carmeli, A. (2003) & Journal Article & 98 & 0.320 & 0.130 & 0.487 \\
\hline $\begin{array}{l}\text { Charbonneau, D. \& Nicol, } \\
\text { A. (2002) }\end{array}$ & Journal Article & 84 & 0.268 & 0.057 & 0.457 \\
\hline Cintron, N. E. (2004) & Dissertation & 355 & 0.110 & 0.006 & 0.212 \\
\hline $\begin{array}{l}\text { Coetzee, C. \& Schapp, P. } \\
(\text { (2004) }\end{array}$ & Journal Article & 100 & 0.149 & -0.048 & 0.336 \\
\hline Collins, V. L. (2001) & Dissertation & 60 & 0.037 & -0.221 & 0.291 \\
\hline $\begin{array}{c}\text { Condren, T., Martin, B. N., \& } \\
\text { Hutchinson, S. (2006) }\end{array}$ & Journal Article & 32 & 0.033 & -0.338 & 0.394 \\
\hline $\begin{array}{l}\text { Cote', S. \& Miners, C. T. H. } \\
\quad(2006)\end{array}$ & Journal Article & 175 & 0.190 & 0.043 & 0.329 \\
\hline Curry, S. M. (2004) & Dissertation & 60 & 0.471 & 0.247 & 0.647 \\
\hline D'Alessio, F. A. (2006) & Dissertation & 375 & 0.160 & 0.060 & 0.257 \\
\hline Danehy, L. S. (2005) & Dissertation & 39 & 0.673 & 0.328 & 0.860 \\
\hline $\begin{array}{c}\text { Dulewicz, C., Young, M. \& } \\
\text { Dulewicz, V. (2005) }\end{array}$ & Journal Article & 103 & 0.330 & 0.146 & 0.492 \\
\hline $\begin{array}{c}\text { Dulewicz, V., Higgs, M. \& } \\
\text { Slaski, M. (2003) }\end{array}$ & Journal Article & 53 & 0.321 & 0.056 & 0.544 \\
\hline Evelyn, J. C. (2001) & Thesis & 76 & 0.900 & 0.846 & 0.936 \\
\hline Fall, M. J. (2004) & Dissertation & 330 & 0.840 & 0.805 & 0.869 \\
\hline $\begin{array}{l}\text { Gardner, L. \& Stough, C. } \\
\text { (2002) }\end{array}$ & Journal Article & 110 & 0.595 & 0.459 & 0.704 \\
\hline Hanley, J. S. (2004) & Dissertation & 37 & 0.552 & 0.277 & 0.743 \\
\hline Hartsfield, M. (2003) & Dissertation & 124 & 0.560 & 0.426 & 0.670 \\
\hline Hayward, B. A. (2005) & Thesis & 377 & 0.670 & 0.611 & 0.722 \\
\hline Heiken, S. E. (2007) & Dissertation & 62 & 0.505 & 0.292 & 0.670 \\
\hline Higgs, M. (2002) & Journal Article & 70 & 0.377 & 0.156 & 0.562 \\
\hline $\begin{array}{l}\text { Kerr, R., Garvin, J., Heaton, } \\
\text { N. \& Boyle, E. (2005) }\end{array}$ & Journal Article & 1197 & 0.390 & 0.341 & 0.437 \\
\hline $\begin{array}{l}\text { Lee, S. \& Olszewski- } \\
\text { Kubilius, P. (2006) }\end{array}$ & Journal Article & 234 & 0.000 & -0.128 & 0.128 \\
\hline Macik-Frey, M. (2007) & Dissertation & 112 & 0.241 & 0.058 & 0.409 \\
\hline
\end{tabular}




\begin{tabular}{|c|c|c|c|c|c|}
\hline $\begin{array}{l}\text { Palmer, B., Walls, M., } \\
\text { Burgess, Z. \& Stough, } \\
\text { C. (2001) }\end{array}$ & Journal Article & 43 & 0.196 & -0.111 & 0.469 \\
\hline Reed, T. G. (2005) & Dissertation & 67 & 0.782 & 0.667 & 0.861 \\
\hline Rosete, D. (2005) & $\begin{array}{l}\text { Conference } \\
\text { Paper }\end{array}$ & 116 & 0.387 & 0.220 & 0.531 \\
\hline $\begin{array}{l}\text { Rosete, D. \& Ciarrochi, J. } \\
\text { (2005) }\end{array}$ & Journal Article & 149 & 0.210 & 0.051 & 0.358 \\
\hline Schmitz, S. A. (2004) & Dissertation & 38 & 0.559 & 0.291 & 0.745 \\
\hline Schulte, M. J. (2002) & Dissertation & 103 & 0.295 & 0.108 & 0.462 \\
\hline Schumacher, L. A. (2005) & Dissertation & 34 & 0.199 & -0.149 & 0.503 \\
\hline $\begin{array}{l}\text { Semadar, A., Robbins, G. \& } \\
\text { Ferris, G. R. (2006) }\end{array}$ & Journal Article & 136 & 0.250 & 0.085 & 0.401 \\
\hline $\begin{array}{l}\text { Sivanathan, N. \& Fekken, G. } \\
\text { C. (2002) }\end{array}$ & Journal Article & 58 & 0.400 & 0.158 & 0.597 \\
\hline $\begin{array}{l}\text { Slaski, M. \& Cartwright, S. } \\
\quad(2002)\end{array}$ & Journal Article & 221 & 0.219 & 0.090 & 0.341 \\
\hline $\begin{array}{c}\text { Stone, H., Parker, J. D. \& } \\
\text { Woods, L. M. (2005) }\end{array}$ & $\begin{array}{l}\text { Commissioned } \\
\text { Study }\end{array}$ & 410 & 0.230 & 0.136 & 0.319 \\
\hline $\begin{array}{l}\text { Sy, T., Tram, S. \& O'Hara, L. } \\
\text { A. (2005) }\end{array}$ & Journal Article & 187 & 0.180 & 0.037 & 0.315 \\
\hline Tang, H. V. (2007) & Dissertation & 100 & 0.650 & 0.517 & 0.752 \\
\hline Vartanian, L. (2006) & Dissertation & 113 & 0.165 & -0.071 & 0.384 \\
\hline Webb, S. (2004) & Thesis & 112 & 0.190 & 0.005 & 0.363 \\
\hline Webb, S. (2005) & Dissertation & 117 & -0.030 & -0.210 & 0.152 \\
\hline Weinberger, L. A. (2003) & Dissertation & 133 & 0.078 & -0.093 & 0.245 \\
\hline $\begin{array}{l}\text { Wong, C. \& Law, K. S. } \\
\text { (2002) }\end{array}$ & Journal Article & 146 & 0.130 & -0.033 & 0.286 \\
\hline $\begin{array}{l}\text { Note: } \mathrm{Cl}=\text { confidence } \\
\text { interval }\end{array}$ & & & & & \\
\hline
\end{tabular}

To examine for possible publication bias, several methods were employed by the researchers. A funnel plot of the standard error on the vertical axis and the converted Fisher's $Z$ effect size on the horizontal axis was computed and examined. The plot in Figure 1 revealed a largely symmetrical distribution around the mean effect size with no visual indications of extreme outliers, suggesting that the probability of publication bias is low. 


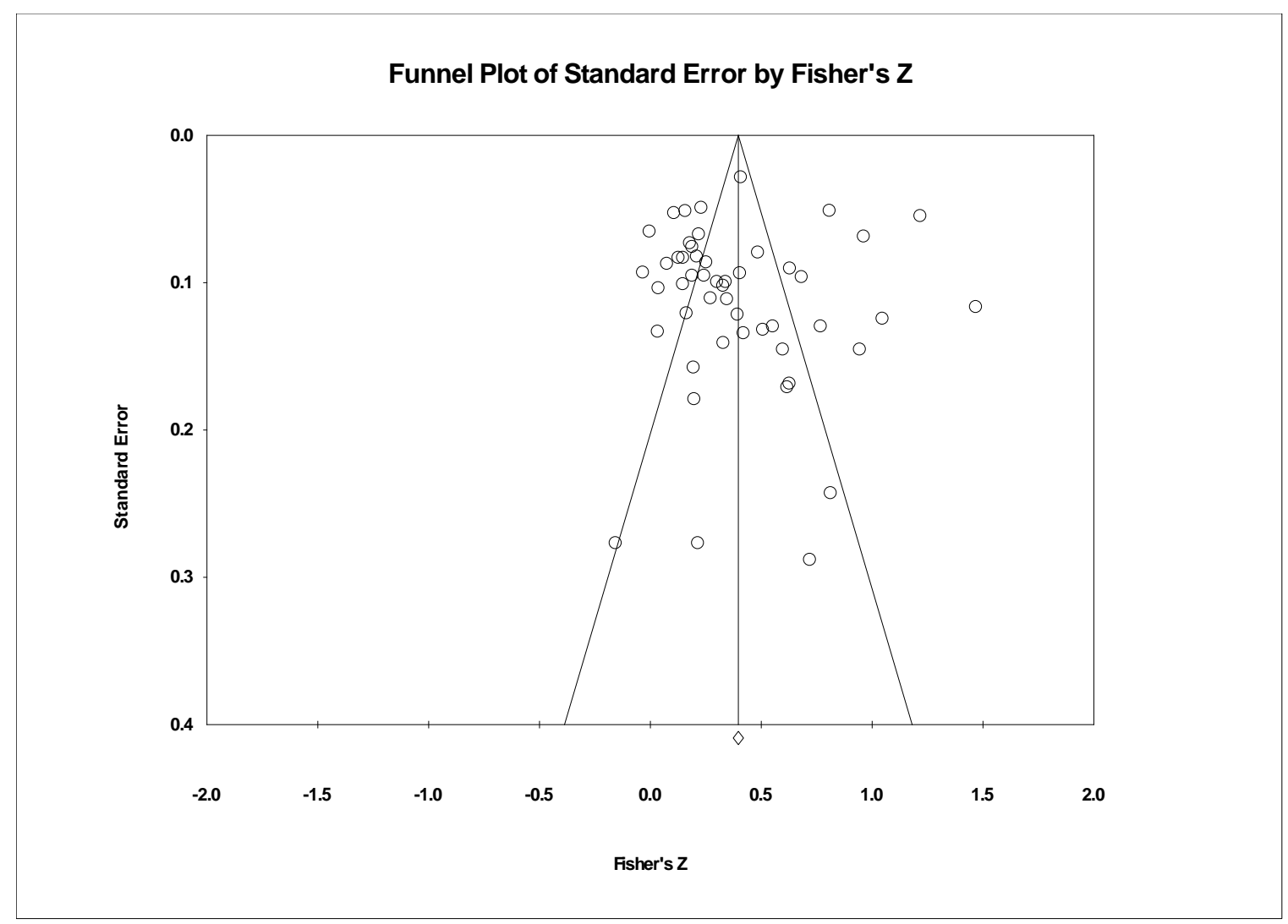

Figure 1: Funnel Plot of Standard Error by Fisher Z

Further analysis for publication bias incorporated the calculation of a fail-safe $\mathrm{N}$. The fail-safe $\mathrm{N}$ estimates the number of unpublished studies needed to nullify the positive effect found between emotional intelligence and leadership effectiveness (Lipsey \& Wilson, 2001). This meta-analysis incorporates data from 48 studies and using the Comprehensive Meta-Analysis Software (Borenstein, Hedges, Higgins, \& Rothstein, 2005), the fail-safe $N$ is 1,275 . This means that the researcher would need to locate and include 1,275 null studies in order for the combined 2-tailed $p$-value to exceed 0.05 . In other words, there would need to be 235 missing studies that show a negative or non-significant effect for every observed study for the effect to be nullified. The fail-safe $\mathrm{N}$ test supports the other data that publication bias was likely not an issue since $60 \%$ of the studies included were unpublished sources.

\section{Discussion}

The results of this study suggest that emotional intelligence may now need to be considered as a component of leadership effectiveness and as such, changes need to be considered in the preparation for and practice of educational leadership. Developing skills associated with emotional intelligence, no longer a "soft skill", and implementing a leadership style in practice that is reflective of emotional intelligence may support 
greater levels of effectiveness. Given the demanding nature of educational leadership in the current climate of accountability and standards, continued calls for reform, strenuous recruitment and retention efforts for highly qualified staff, and ever changing landscape of reform and demographics, educational leaders may be hard pressed to ignore this finding.

Regarding the preparation of future educational leaders, Educational Leadership Preparation Programs might want to consider incorporating the role of emotions and emotional intelligence in their course design and training experiences. Ashkanasy and Dasborough (2003) support the view that emotions are critical in understanding organizations and in the teaching of leadership. Skillful handling of situations and people, reflective of leaders aware of the importance of emotional intelligence should be given the same attention and importance as the more traditional leadership tasks of budget, finance, and operational skills. Another likely outcome of this finding is the incorporation of a more formal evaluation of emotional intelligence in preservice and current educational leaders.

Several directions for future research can be offered from the current study. Given the availability of several models of emotional intelligence in the literature, an examination of the effectiveness of specific models and their impact on leadership effectiveness is warranted. For example, do the specific and unique components of the various models of emotional intelligence offer differing levels of impact on leadership effectiveness? Also, given that this study focused exclusively on correlational studies of emotional intelligence and leadership effectiveness, further meta-analytic research that examined these outcomes among studies incorporating different methodological procedures is warranted.

\section{References}

References marked with an asterisk indicate studies included in the meta-analysis.

Andersen, J. A. (2000). Leadership and leadership research. The Current State of Business Disciplines, 5, 2267-2287.

Antonakis, J. (2004). On why emotional intelligence will not predict leadership effectiveness beyond IQ or the "Big Five": An extension and rejoinder. Organizational Analysis, 12(2), 171-182.

Ashforth, B. E., \& Humphrey, R. H. (1995). Emotion in the workplace: A reappraisal. Human Relations, 48(2), 97-99.

Ashkanasy, N. M., \& Dasborough, M. T. (2003). Emotional awareness and emotional intelligence in leadership teaching. Journal of Education for Business, 79(1), 1822. 
Ashkanasy, N., Hartel, C. E. J., \& Daus, C. S. (2002). Diversity and Emotion: The new frontiers in organizational behavior research. Journal of Management, 28(3), 307338.

Bar-On, R. (1997). Bar-On Emotional Quotient Inventory: Technical manual. Toronto, ON: Multi-Health Systems.

Bar-On, R. (2006). The Bar-On model of emotional-social intelligence (ESI). Psicothema, 18(suppl.), 13-25.

Barbuto, J. E., \& Burbach, M. E. (2006). The emotional intelligence of transformational leaders: A field study of elected officials. The Journal of Social Psychology, 146(1), 51-64.

Barchard, K. A. (2003). Does emotional intelligence assist in prediction of academic success? Educational and Psychological Measurement, 63(5), 840-858.

Barling, J., Slater, F., \& Kelloway, E. R. (2000). Transformational leadership and emotional intelligence: An exploratory study. Leadership and Organization Development Journal, 21(3), 157-161.

Bass, B. M. (1990). From transactional to transformational leadership: Learning to share the vision. Organizational Dynamics, 18(3), 19-31.

Bass, B. M., \& Avolio, B. J. (1993). Transformational leadership: A response to critiques. In M. M. Chemers \& R. Ayman (Eds.) Leadership theory and research: Perspectives and directions. New York: Free Press.

Bass, B., \& Avolio, B. (2000). Multifactor leadership questionnaire ( $2^{\text {nd }}$ ed.). Redwood City, CA: Mind Garden, Inc.

*Batastini, S. D. (2001). The relationship among students' emotional intelligence, creativity and leadership. Unpublished doctoral dissertation, Drexel University.

*Baumann, D. M. (2006). The relationship between the emotional competence and the leadership effectiveness of hall directors. Unpublished doctoral dissertation, University of Missouri-Columbia.

${ }^{*}$ BeShears, R. S. (2004). The ability of emotional intelligence to predict transformational leadership when personality, affect, and cognitive ability are controlled. Ph.D. dissertation, Wayne State University, United States -- Michigan. Retrieved October 31, 2009, from Dissertations \& Theses: A\&I. (Publication No. AAT 3151327).

Borenstein M., Hedges L., Higgins J., \& Rothstein H. (2005). Comprehensive MetaAnalysis (Version 2) [Computer Software]. Englewood, NJ: Biostat. 
Borenstein, M., Hedges, L., Higgins, J., \& Rothstein, H. (2007). Introduction to metaanalysis. Retrieved January 29, 2008, from http://www.meta-analysis.com

*Bradberry, T. R. (2003). Emotional intelligence and organizational justice as correlates of leader job performance in organizations. Unpublished doctoral dissertation, Alliant International University.

*Brown, F. W., Bryant, S. E., \& Reilly, M. D. (2006). Does emotional intelligence-as measured by the EQI-influence transformational leadership and/or desirable outcomes? Leadership and Organizational Development Journal, 27(5), 330-351.

Brown, K. D. (2005). Relationship between emotional intelligence of leaders and motivational behavior of employees. D.M. dissertation, University of Phoenix, United States -- Arizona. Retrieved October 31, 2009, from Dissertations \& Theses: A\&I. (Publication No. AAT 3183509).

*Buford, B. A. (2001). Management effectiveness, personality, leadership, and emotional intelligence: A study of the validity evidence of the Emotional Quotient Inventory (EQ-i). Ph.D. dissertation, The University of lowa, United States -lowa. Retrieved October 31, 2009, from Dissertations \& Theses: A\&I. (Publication No. AAT 3034082).

*Burbach, M. E. (2004). Testing the relationship between emotional intelligence and fullrange leadership as moderated by cognitive style and self-concept. Ph.D. dissertation, The University of Nebraska - Lincoln, United States -- Nebraska. Retrieved October 31, 2009, from Dissertations \& Theses: A\&I. (Publication No. AAT 3126944).

${ }^{*}$ Carmeli, A. (2003). The relationship between emotional intelligence and work attitudes, behavior and outcomes: An examination among senior managers. Journal of Managerial Psychology, 18(7/8), 788-813.

${ }^{*}$ Charbonneau, D., \& Nicol, A. (2002). Emotional intelligence and leadership in adolescents. Personality and Individual Differences, 33, 1101-1113.

${ }^{*}$ Cintron, N. E. (2004). The effects of biculturalism, emotional intelligence, and acculturation on motivation to lead of expatriate Latina business leaders and entrepreneurs: An exploratory investigation. Ph.D. dissertation, Regent University, United States -- Virginia. Retrieved October 31, 2009, from Dissertations \& Theses: A\&I. (Publication No. AAT 3140596).

${ }^{*}$ Coetzee, C., \& Schaap, P. (2004). The relationship between leadership styles and emotional intelligence. Paper presented at the $6^{\text {th }}$ Annual Conference of the Society of Industrial and Organizational Psychology, as part of the symposium. 
${ }^{*}$ Collins, V. L. (2001). Emotional intelligence and leader success. Ph.D. dissertation, The University of Nebraska - Lincoln, United States -- Nebraska. Retrieved October 31, 2009, from Dissertations \& Theses: A\&I. (Publication No. AAT 3034371).

${ }^{*}$ Condren, T. D., Martin, B. N., \& Hutchinson, S. (2006, Summer). What does emotional intelligence and gender have to do with leadership...or does it? Advancing Women in Leadership Online Journal, 21. Retrieved November 21, 2007, from http://www.advancingwomen.com/awl/summer2006/Condren_Martin_Hutchinson .html

${ }^{*}$ Cote, S., \& Miners, C. T. (2006, March). Emotional intelligence, cognitive intelligence, and job performance. Administrative Science Quarterly, 51, 1-28.

${ }^{*}$ Curry, S. M. (2004). Examining the relationship between self-perceived emotional intelligence and leadership in school principals. Ed.D. dissertation, Regent University, United States -- Virginia. Retrieved October 31, 2009, from Dissertations \& Theses: A\&I. (Publication No. AAT 3142352).

${ }^{*}$ D'Alessio, F. A. (2006). The influence of personality, critical thinking, and emotional intelligence attributes in Peruvian managers' leadership. D.B.A. dissertation, University of Phoenix, United States -- Arizona. Retrieved October 31, 2009, from Dissertations \& Theses: A\&I. (Publication No. AAT 3235055)

*Danehy, L. S. (2005). The relationship between emotional intelligence and leadership in NCAA division III college coaches. Ed.D. dissertation, Wilmington College (Delaware), United States -- Delaware. Retrieved October 31, 2009, from Dissertations \& Theses: A\&I. (Publication No. AAT 3209627)

Downey, L. A., Papageorgiou, V., \& Stough, C. (2006). Examining the relationship between leadership, emotional intelligence and intuition in senior female managers. Leadership \& Organization Development Journal, 27(4), 250-264.

*Dulewicz, C., Young, M., \& Dulewicz, V. (2005). The relevance of emotional intelligence for leadership performance. Journal of General Management, 30(3), 71-86.

Dulewicz, V., \& Higgs, M. (2000). Emotional intelligence a review and evaluation study. Journal of Managerial Psychology, 15(4), 341-372.

Dulewicz, V., \& Higgs, M. (2003). Leadership at the top: The need for emotional intelligence in organizations. The International Journal of Organizational Analysis, 11(3), 193-210. 
*Dulewicz, V., Higgs, M., \& Slaski, M. (2003). Measuring emotional intelligence: Content, construct and criterion-related validity. Journal of Managerial Psychology, 18(5), 405-420.

*Evelyn, J. C. (2001). Emotional intelligence as a predictor of consideration behaviors, which lead to leadership effectiveness. Unpublished doctoral dissertation, California State University-San Bernardino.

${ }^{*}$ Fall, M. J. (2004). Emotinal competencies as a factor in the leadership of elementary school principals. Ed.D. dissertation. Central Michigan University. United States - Michigan. Retrieved October 31, 2009, from Dissertations \& Theses: A\&I. (Publication No. AAT 3150970.

*Gardner, L., \& Stough, C. (2002). Examining the relationship between leadership and emotional intelligence in senior level managers. Leadership \& Organizational Development Journal, 23(2), 68-78.

Glass, G. V., McGaw, B. \& Smith, M. L. (1981). Meta-analysis in social research. Beverly Hills: Sage.

Goleman, D. (1995). Emotional intelligence. New York: Bantum Books.

Goleman, D. (1998). Working with emotional intelligence. New York: Bantam.

Goleman, D., Boyatzis, R., \& McKee, A. (2002). Primal leadership: Realizing the power of emotional intelligence. Boston: Harvard Business School Press.

${ }^{*}$ Hanley, J. S. (2004). The impact of participation in a leadership development program on emotional intelligence, leader behaviors, and leader outcome and one Midwestern university. Unpublished doctoral dissertation, Saint Mary's University of Minnesota.

Hartman, L. (1999). A psychological analysis of leadership effectiveness. Strategy \& Leadership, 27(6), 30-32.

*Hartsfield, M. K. (2003). The internal dynamics of transformational leadership: Effects of spirituality, emotional intelligence, and self-efficacy. Ph.D. dissertation, Regent University, United States -- Virginia. Retrieved October 31, 2009, from Dissertations \& Theses: A\&I. (Publication No. AAT 3090425).

${ }^{*}$ Hayward, B. A. (2005). Relationship between employee performance, leadership and emotional intelligence in a South African parastatal organization. Unpublished doctoral dissertation, Rhodes University.

${ }^{*}$ Heiken, S. E. (2007). The perceived relationship between emotional intelligence and leadership effectiveness in school leaders: A comparison of self ratings with 
those of superiors and reports. Ed.D. dissertation, Wilmington College (Delaware), United States -- Delaware. Retrieved October 31, 2009, from Dissertations \& Theses: A\&I. (Publication No. AAT 3246674).

*Higgs, M. (2002). Do leaders need emotional intelligence?: A study of the relationship between emotional intelligence and leadership of change. International Journal of Organizational Behaviour, 5(6), 195-212.

Hoffman, B. J., \& Frost, B. C. (2006). Multiple intelligences of transformational leaders: An empirical examination. International Journal of Manpower, 27(1), 37-51.

*Kerr, R., Gavin, J., Heaton, N., \& Boyle, E. (2005). Emotional intelligence and leadership effectiveness. Leadership \& Organization Development Journal, 27(4), 265-279.

Kouzes, O., \& Posner, B. (1995). The leadership challenge. San Francisco, CA: JosseyBass.

Leban, W., \& Zulauf, C. (2004). Linking emotional intelligence abilities and transformational leadership styles. The Leadership \& Organization Development Journal, 25(7), 554-564.

*Lee, S., \& Olszewski-Kubilius, P. (2006). The emotional intelligence, moral judgment, and leadership of academically gifted adolescents. Journal for the Education of the Gifted, 30(1), 29-67,119.

Lipsey, M. W., \& Wilson, D. B. (2001). Practical meta-analysis. Thousand Oaks, CA: Sage.

*Macik-Frey, M. (2007). Communication-centered approach to leadership: The relationship of interpersonal communication competence to transformational leadership and emotional intelligence. Ph.D. dissertation, The University of Texas at Arlington, United States -- Texas. Retrieved October 31, 2009, from Dissertations \& Theses: A\&I. (Publication No. AAT 3273961).

Mandell, B., \& Pherwani, S. (2003). Relationship between emotional intelligence and transformational leadership style: A gender comparison. Journal of Business and Psychology, 17(3), 387-404.

Mayer, J. D., \& Caruso, D. (2002). The effective leader: Understanding and applying emotional intelligence. Ivey Business Journal Online, Nov/Dec, 1-6.

Mayer, J. D., \& Salovey, P. (1997). What is emotional intelligence? In P. Salovey \& D. J. Sluyter (Eds.), Emotional development and emotional intelligence (pp. 3-31). New York: Basic Books. 
Mayer, J. D., Salovey, P., \& Caruso, D. R. (2000). Models of emotional intelligence. In R. Sternberg (Ed.), Handbook of intelligence. Cambridge, UK: Cambridge University Press.

McEnrue, M. P., \& Groves, K. (2006). Choosing among tests of emotional intelligence: What is the evidence? Human Resource Development Quarterly, 17(1), 9-42.

Multi Health Systems, Inc. (2002). Mayer Salovey Caruso Emotional Intelligence TestMSCEIT [Brochure]. North Tonawanda, NY: Author.

Nahavandi, A. (2003). The art and science of leadership. Upper Saddle River, NJ: Prentice-Hall.

Northouse, P. G. (2006). Leadership: Theory and practice $\left(4^{\text {th }}\right.$ ed.). Thousand Oaks: Sage.

*Palmer, B., Walls, M., Burgess, Z., \& Stough, C. (2001). Emotional intelligence and effective leadership. Leadership \& Organization Development Journal, 22(1), 510.

${ }^{*}$ Reed, T, G. (2005). Elementary principal emotional intelligence, leadership behavior, and openness: An exploratory study. Ph.D. dissertation, The Ohio State University, United States -- Ohio. Retrieved October 31, 2009, from Dissertations \& Theses: A\&l. (Publication No. AAT 3197801).

${ }^{*}$ Rosete, D. (2005, June). A Leader's Edge: What Attributes Make an Effective Leader? Paper presented at the fifth Annual Emotional Intelligence Conference, Netherlands.

${ }^{*}$ Rosete, D., \& Ciarrochi, J. (2005). Emotional intelligence and its relationship to workplace performance outcomes of leadership effectiveness. Leadership \& Organization Development Journal, 26(5), 388-399.

${ }^{*}$ Schmitz, S. A. (2004). The relationship between emotional intelligence and leadership practices in non-profit human service organizations. Ph.D. dissertation, Northcentral University, United States -- Arizona. Retrieved October 31, 2009, from Dissertations \& Theses: A\&I. (Publication No. AAT 3159470).

*Schulte, M. J. (2002). Emotional intelligence: A predictive or descriptive construct in ascertaining leadership style or a new name for old knowledge? Ph.D. dissertation, Our Lady of the Lake University, United States -- Texas. Retrieved October 31, 2009, from Dissertations \& Theses: A\&I. (Publication No. AAT 3068435).

*Schumacher, L. A. (2005). The relationship between supply managers' emotional intelligence and their performance. Ed.D. dissertation, Bowling Green State 
University, United States -- Ohio. Retrieved October 31, 2009, from Dissertations \& Theses: A\&I. (Publication No. AAT 3175805).

*Semadar, A., Robins, G., \& Ferris, G. R. (2006). Comparing the validity of multiple social effectiveness constructs in the prediction of managerial job performance. Journal of Organizational Behavior, 27(4), 443-461.

*Sivanathan, N., \& Fekken, G. C. (2002). Emotional intelligence, moral reasoning, and transformational leadership. Leadership Organization Development Journal, 23(4), 198-204.

*Slaski, M., \& Cartwright, S. (2002). Health, performance and emotional intelligence: An exploratory study of retail managers. Stress and Health, 18(2), 63-68.

Srivastava, K. B., \& Bharamanaikar, S. R. (2004). Emotional intelligence and effective leadership behaviour. Psychological Studies, 49(2-3), 107-113.

Sternberg, R. J. (Ed.). (2000). Handbook of intelligence. Cambridge, UK: Cambridge University Press.

Stogdill, R. M. (1974). Handbook of leadership. New York: Free Press.

*Stone, H., Parker, J. D. A., \& Wood, L. M. (2005). Report on the Ontario Principals' Council leadership study. Retrieved July 18, 2007, from the Consortium for Research on Emotional Intelligence in Organizations Web site: http://www.eiconsortium. org/reports/opc_leadership_study_final_report.html

*Sy, T., Tram, S., \& O'Hara, L. (2006). Relation of employee and manager emotional intelligence to job satisfaction and performance. Journal of Vocational Behavior, 68(3), 461-473.

*Tang, H. V. (2007). A cross-cultural investigation of academic leaders' emotional intelligence and leadership effectiveness in Taiwan and the United States. Ed.D. dissertation, Texas A\&M University - Kingsville, United States -- Texas. Retrieved October 31, 2009, from Dissertations \& Theses: A\&I. (Publication No. AAT 3274065).

Van Rooy, D. L., \& Viswesvaran, C. (2004). Emotional intelligence: A meta-analytic investigation of predictive validity and nomological net. Journal of Vocational Behavior, 65(1), 71-95.

*Vartanian, L. (2006). The relationship between emotional intelligence and situational leadership II. Ph.D. dissertation, Alliant International University, San Diego, United States -- California. Retrieved October 31, 2009, from Dissertations \& Theses: A\&I. (Publication No. AAT 3247228). 
*Webb, S. (2004). Exploring the relationship of emotional intelligence to transformational leadership within mentoring relationships. Unpublished master's thesis, University of Florida.

*Webb, S. (2005). Examining emotional intelligence and leadership. Ph.D. dissertation, University of South Florida, United States -- Florida. Retrieved October 31, 2009, from Dissertations \& Theses: A\&I. (Publication No. AAT 3197949).

*Weinberger, L. A. (2003). An examination of the relationship between emotional intelligence, leadership style, and perceived leadership effectiveness. Ph.D. dissertation, University of Minnesota, United States -- Minnesota. Retrieved October 31, 2009, from Dissertations \& Theses: A\&I. (Publication No. AAT 3113218)

*Wong, C., \& Law, K. S. (2002). The effects of leader and follower emotional intelligence on performance and attitude: An exploratory study. The Leadership Quarterly, 13(3), 243-274.

\section{About the Author:}

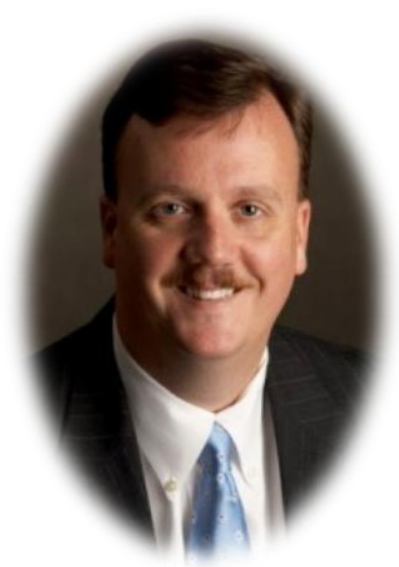

Lane B. Mills, Ph.D. is an Associate Professor in the Department of Educational Leadership, College of Education at East Carolina University. He can be reached at millsl@ecu.edu. 